\title{
島根県松江市 4 小学校における放課後子ども教室の 拠点確保別の活動実態に関する研究 A STUDY ON THE ACTIVITY CONDITIONS OF AFTER SCHOOL BY TYPES OF SERVICE CENTER IN 4 ELEMENTARY SCHOOLS OF MATSUE CITY, SHIMANE PREFECTURE
}

\author{
細田智 久*
}

\section{Tomohisa HOSODA}

\begin{abstract}
The After School makes activities and learning spaces for many students by using school facilities and other public facilities. This study aims to clarify how to use the space and how to support the student at the service rooms by actual survey for 4 elementary schools of Matsue City. The results are as follows.

1. The service center makes by using special subject room, multiple room and exclusive room.

2. The support staff carefully services for small student groups. The half ratio students play the static activities, and another students play the dynamic activities.

3. In case of using large multiple room or exclusive room, students can use to both of static and dynamic activities that encourage by sufficiently furniture. But special room do not have many flexibility in activity and using time.

4. In case of using 3 multiple rooms, students can divide to groups by each activities or grades.
\end{abstract}

Keywords : After School, Elementary School, Survey of Actual Condition, Making Action Space for Children 放課後子ども教室, 小学校, 実態調査, 子どもの居場所づくり

\section{$1-1$. 研究の背景と意義}

我国では、共働きで子どもを育てる若い夫婦の増加に伴い、児童 の放課後や土曜日の過ごし方が問われている。さらに、地域の子ど もを見守る力が減少していく中で、より一層放課後や週末の安全で 良質な览童の居場所づくりの必要性が高まっている。こうした背景 から、文科省は平成 19 年度から「放課後子ども教室推進事業」を 進め、学校の余裕教室等を利用し、親や地域の協力を得て、放課後 や週末にスポーツや体験活動を実施している。さらに厚労省の「放 課後児童健全育成事業」と一体運用され、総称「放課後子どもプラ ン」として、放課後の子どもの学習支援、居場所として大きな役割 を担っている。しかし、急速な整備による不十分な設備、ハード整 備一の補助は初年度のみという制度上の問題、準備室の久如の指摘 もある ${ }^{1)}$ 。こうした中で、平成 21 年 11 月下旬の行政刷新会議に よるいわゆる「事業仕分け」の場において、これまでの国からの補 助事業から地方自治体による実施の流れも示されたことから、今後 は各自治体の土夫によってより魅力的な居場所のあり方が問われて くると考えている。

\section{$1-2$. 研究の目的}

本編は、既存の校舎を使用した放課後子ども教室を実施する松江 市の 4 小学校への実態調査によって、参加児童の点呼などの場所と なる拠点を含めた全活動場所の把握とスタッフ支援の状況、児童の 活動内容や活動の広がりの状況を明らかにすることを目的としてい る。さらに拠点確保別のメリットとデメリットの整理から、地方都
市で進む学校の耐震改修や統合の機会に合わせて、放課後子ども教 室の拠点整備を行う際に留意すべき要点の整理も目的としている。

\section{$1-3$. 調査対象地域の概要}

島根県教育委員会の調查では平成 19 年度の制度スタート時に島

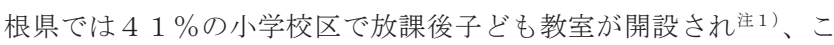
れは同年 12 月時点の全国平均 $26 \%$ 注2) よりも高く、島根県は積 極的に取り組みを始めたことが分る。県内の主要な市における 21 年の校区単位の実施見込みは、松江市（34 校区中の 21 校区）、出雲 市 (38 校区中の 17 校区)、雲南市 (21 校区中の 21 校区)、大田市 $(22$ 校区中の 12 校区)、益田市（19 校区中の 12 校区）である注1)。この 中で出雲市と益田市は「子ども教室と児童クラブと連携した取組み」、 雲南市と大田市は「公民館等、関係機関と連携した取組み」として 展開されている。一方で松江市は「学校・保護者と連携した取組み」 を特色とし、見学会などを通じて保護者の理解を深めた上で順次開 設し、将来的には全小学校区で移動の利便性が高い学校施設を活用 した放課後子ども教室の展開を目指している注3)。こうした松江市 の整備方法は、保護者の要望や地域環境に根ざし、円滑に開設校を 増やしている好例と判断した。実際に平成 19 年の 15 校区から、2 2 年では 29 校区（開設見込み含む）に倍増しており、県内他市では みられない増加ペースである注1)。さらに、松江市は人口 20 万人規 模で、人口密度においても全国の市で中位グループに位置すること から、松江市で得られた知見は多くの地方都市の放課後子ども教室 の展開にも有益な情報になると判断した注 4 )。

\footnotetext{
* 独立行政法人国立高等専門学校機構

米子工業高等専門学校建築学科 准教授·博士 (工学)
}

Assoc. Prof., Dept. of Architecture, Yonago National College of Technology, Dr. Eng. 


\section{1-4. 既往研究との関係}

斎尾・長谷 ${ }^{2)}$ は、放課後子ども教室の本格運用前の先進的地域お よび東京近郊の調查によって、安全安心な居場所づくりの在り方を 分析している。松本・ 中山 ${ }^{3 \cdot 4)}$ は、学童保育と放課後子ども教室 の一体化事業の調查を行い、拠点付近での活動の様子を論じている。 以上の既存研究と比較して、本研究は、1. 放課後子ども教室 (以下、 「子ども教室」と略す）が本格運用された後にその実態を調查した こと、2. 地方都市の低層校舎の性格を活かした改修事例を含むこと、 3. 拠点だけでなく活動場所の全体を把握して、児童の活動内容の全 体像を明らかにしていることの 3 点を特色としている。

\section{$1-5$. 研究の構成}

4 章では、調查対象 4 校の子ども教室の拠点や利用室の位置と登 録人数の概要を整理している。 5 章では、子ども教室における全体 像を把握するため、時間別場所別の活動児童数の割合を分析し、児 童の活動場所の選択傾向、性差による活動場所の違い、スタッフの 支援方法を考察する。6 章では、各活動場所を使った具体的な活動 内容を明らかにするため、場所別活動別にみた活動内容の分析図を 分析し、拠点室の役割や活動の特色にあった場所の作り方を考察す る。 7 章では、以上の分析結果から、4 校の調查結果からではある が、学校全体の配置の中での拠点室の位置も考慮した上で、拠点室 の配置および設置方法別のメリットとデメリットを考察する。最後 に 8 章で結論を述べる。

\section{2. 松江市の放課後子ども教室の整備状況}

1 ）松江市の整備状況（表 1 ）: 松江市教育委員会へのヒアリング調 查では平成 22 年 4 月時点で松江市内 34 校中 26 校で学童保育 (児童クラブ）を実施し、2 0 校で子ども教室を実施している。こ の内で 15 校は学童保育と子ども教室の両方を実施している。子ど も教室の 20 校の内で 11 校が学校施設を利用し、その他は公民館 等を利用している。また、松江市内の子ども教室の運営主体は公民 館で、公民館スタッフが地域の支援スタッフの協力を得て担ってい る。これは松江市民が町内会費から公民館運営費を拠出している形 態に所以する。

表 1 松江市内の小学校における学童保育と放課後子ども教室 の開設状況と調查 4 例の位置付け

\begin{tabular}{|c|c|c|c|}
\hline \multirow{6}{*}{$\begin{array}{l}\text { 松江市 } \\
\text { 小学校 } \\
34 \text { 校 }\end{array}$} & $\begin{array}{l}\text { 学童保育と放課後子ども } \\
\text { 教至の開設況 (H22.4) }\end{array}$ & $\begin{array}{l}\text { 子ど } \\
\text { の利 }\end{array}$ & \multirow{3}{*}{ 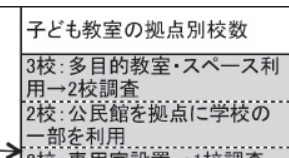 } \\
\hline & $\begin{array}{l}\text { 11校:学童保育(児童クラ } \\
\text { ブ)のみ開設 }\end{array}$ & & \\
\hline & \begin{tabular}{|l} 
15校: 学童保育と放課後 \\
子ども教室の両方を開設
\end{tabular} & & \\
\hline & & & 2校:体育館-校庭利用 \\
\hline & & & 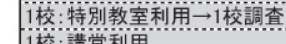 \\
\hline & 3校:どちらも開設 & & 1 校 \\
\hline
\end{tabular}

2 ）学童保育と放課後子ども教室の相違点：学童保育は、働く親を 持つ子どもの放課後及び長期休業中の生活の保障を目的とし、遊び や生活の場を与える有料の公的サービス（月 5 千円程度）で、松江 市では学校内に専用の保育室を持ち、軽食も提供される。一方で、 放課後子ども教室は、すべての児童生徒を対象に体験・交流活動の 場を提供し、原則無料のサービスである。両方が実施されている松 江市内の学校では、子ども教室の参加児童は学童保育室には入れな いが、学童保育の参加児童は子ども教室の子どもと利用室などで一 緒に活動している。

\section{3. 研究方法}

1) ヒアリング調查：H 21 年度及びH 22 年度の年度当初に松江 市教育委員会へのヒアリング調查を行い、松江市の現在の子ども教 室の整備状況と今後の実施校拡大を目指した取り組みについて聞き 取りを行った。

2 ）調查対象校の選定：表 2 に示寸ように、ヒアリング調査の過程 で、学校施設を利用して子ども教室を行う 11 校の内で円滑に運営 され、ハード面で校舎内での拠点室の整備方法が異なる 4 校を調査 対象として選定した。選定は、1 1 校の内でまず校舎への拠点室の 整備のあり方を考察できるように、公民館を拠点とする 2 校を除き、 次に体育館や講堂を拠点室とする 3 校も宿題支援が十分に行い難い 状況にあるため除いた。残る 6 校の内、施設面で不十分なプレハブ 1 校と大規模校のために人数制限を実施中で運営上課題のある 1 校 を除く 4 校とした。

表 2 拠点室の設置状況と運営面の課題を考慮した 調查対象校の位置付け

\begin{tabular}{|c|c|c|c|}
\hline 子ども教室の拠点別校数 & $\begin{array}{l}\text { 学校名 } \\
\text { (下線の学 } \\
\text { 校詩調査) }\end{array}$ & $\begin{array}{l}\text { 体育館·講堂を } \\
\text { 除校全内設置|拠 }\end{array}$ & $\begin{array}{l}\text { 運営面の課題(松江市教育委員 } \\
\text { 会ヒアリング結果より) }\end{array}$ \\
\hline \multirow[t]{3}{*}{$\begin{array}{l}\text { 3校:多目的教室·スペー } \\
\text { ス利用 }\end{array}$} & NO & $\bullet$ & $\begin{array}{l}\text { 全校児童約 } 1000 \text { 人で子ども教室 } \\
\text { は人数制限を実施中 }\end{array}$ \\
\hline & FU & (2F多目的) & \\
\hline & $\underline{\text { SI }}$ & (1F多目的) & \\
\hline \multirow{2}{*}{$\begin{array}{l}\text { 2校: 公民館を拠点に学校 } \\
\text { の一部を利用 }\end{array}$} & UC & - & \\
\hline & KO & - & \\
\hline \multirow[t]{2}{*}{ 2校:専用室設置 } & NA & (旧幼稚園舎) & \\
\hline & $\mathrm{KA}$ & Q(プレハブ) & \\
\hline \multirow[t]{2}{*}{ 2校: 体育館·校庭利用 } & $\mathrm{HO}$ & - & 樾点室が体育館のた分に行い宿題支 \\
\hline & TA & - & 軷が点室が分には体育館のためい、宿題支 \\
\hline 1校:特別教室利用 & $\underline{\text { TI }}$ & - & \\
\hline 1校: 講堂利用 & 00 & - & $\begin{array}{l}\text { 㩏点室が講堂のため゙、宿題支援 } \\
\text { が十には行い難 }\end{array}$ \\
\hline
\end{tabular}

3 ) スタッフヒアリング調查 : 各校に 1 名ずつ配置されているコー ディネーターと複数配置されている支援スタッフ（いずれも地域住 民や児童保護者）にヒアリング調査を行うと共に、拠点や利用室な どの撮影を行った。

4 ）実態調查：上記で得た資料を基に各室の家具レイアウト図を作 成し、H 21 年 6 月と 9 月に N A 学校、6 月と 10 月に T I 小、 $\mathrm{H} 22$ 年 7 月に F U小、 7 月に S I 小の 4 例を対象に 2 度ずつ注 5 ) 調查シートを用いた 15 分毎の活動内容プロット調查を行った。調 查シートには、児童とスタッフの位置と活動内容、使用家具を記入 した。

4. 4 校における放課後子ども教室の利用室の配置と概要（表 3 ）

1) T I 小（図 1 ） は、学校の家庭科室を拠点とし、その周辺の体 育館と中庭が良く利用され、校庭も利用している。拠点が家庭科室 のため、私物の管理収納スペースを設けることができず、マットを 敷いてかばんを置いている。全校児童は 362 名で子ども教室の登 録人数は 76 名である。月曜と木曜の週 2 日活動している。拠点の 家庭科室の横には学童保育の専用室（登録６０名）を持つ。表 3 に 示すスタッフの支援方法では学年の上下関係に捉われず、皆で一緒 に遊ぶ雰囲気を大切にし、スタッフは見守りを中心に支援している。 2 ） NA小（図 2 ）は、校舎に隣接寸る旧幼稚園舎を改修した専用 
室を拠点とし、校庭、裏山や校舎周辺の水田などを利用している。 それ以外にも体育館・図書館を利用できるが、調查時には利用する 児童はいなかった。なお、校舎から専用室へは履き替えは必要だが、 専用室前の庇が学校昇降口前のバルコニー下まで連続しており、雨 に濡れずにアクセスできる。拠点内に収納スペースを確保し教材の 管理ができている。全校児童は 35 名で登録人数は 15 名である。 月曜から金曜の週 5 日活動している。学童保育は実施していない。 支援方法では、学年の上下関係にとらわれず、皆で一緒に遊ぶ雾囲 気を大切にしており、スタッフは見守りを中心に支援している。

3）ＦＵ（図３）は、2 階の多目的室を拠点とし、図書室、体育 館、中庭、前庭を利用している。多目的室と図書室は隣接している。 全校児童は 250 名で登録人数は 47 名である。月・金曜の週 2 日 活動している。多目的室下の 1 階に学童保育の専用室（登録 50 名） を持つ。支援方法では、家庭的な雾囲気を大切にし、スタッフは見 守りを中心に支援している。

4）S I 小（図 4) は、旧校舎の改修部分の廊下に対してオープン な多目的ホール (のびのびホール) を拠点とし、両隣りの「いこい ルーム」「きらきらルーム」や図書コーナー、体育館、校庭を利用し ている。「いこいルーム」と「きらきらルーム」は、学年の高低別で 宿題を行えるようになっている。全校児童は 150 名で登録人数は 半数を超える 80 名である。月曜のみ活動している。学童保育は実 施していない。支援方法では、自由に活動させてスタッフは見守り を中心に支援している。スタッフの一部にサッカーを熱心に指導す る人がおり、校庭でサッカーを楽しむ児童が比較的多い。

表 3 調查 4 校の概要整理表

\begin{tabular}{|c|c|c|c|c|c|}
\hline \multirow{2}{*}{\multicolumn{2}{|c|}{$\begin{array}{l}\text { 学校名 } \\
\text { 全校児童数 }\end{array}$}} & \multirow{2}{*}{$\begin{array}{l}\text { TI小学校 } \\
362 \text { 名 } \\
\end{array}$} & \multirow{2}{*}{$\begin{array}{l}\text { NA小学校 } \\
35 \text { 名 } \\
\end{array}$} & \multirow{2}{*}{\begin{tabular}{|l|} 
FU小学校 \\
250名 \\
\end{tabular}} & \multirow{3}{*}{\begin{tabular}{|l|}
\multicolumn{1}{|c|}{ SI小学校 } \\
150 名 \\
SI公民館 \\
\end{tabular}} \\
\hline & & & & & \\
\hline 放課後 & 運営支援 & TI公民館 & FU公民館 & FU公民館 & \\
\hline \multirow[t]{6}{*}{$\begin{array}{l}\text { 子ども } \\
\text { 教室 }\end{array}$} & 拠点整備方法 & $\begin{array}{l}1 \text { 階家庭科室を活 } \\
\text { 帮し道具箱などを } \\
\text { 整偷 }\end{array}$ & $\begin{array}{l}\text { 幼稚園舎を改修 } \\
\text { して専用室として } \\
\text { 整備 }\end{array}$ & $\begin{array}{l}\text { 2階多目的室 } \\
\text { を活用 }\end{array}$ & $\begin{array}{l}\text { 1階の多目的ホー } \\
\text { ルと両脇の多目的 } \\
\text { 室を活用 }\end{array}$ \\
\hline & スケジュール & \begin{tabular}{|l} 
月曜15-17時 \\
木曜16-17時
\end{tabular} & $\begin{array}{l}\text { 月曜15:10-17時 } \\
\text { 火-金曜15:30-17 } \\
\text { 時 }\end{array}$ & $\begin{array}{l}\text { 月曜15-17時 } \\
\text { 金曜15-17時 }\end{array}$ & 月曜15:30-16:45 \\
\hline & 登録児童数 & 76名 & 15名 & 47名 & 80名 \\
\hline & スタッフ数 & 6名程度 & 3名程度 & 5名程度 & 8名程度 \\
\hline & 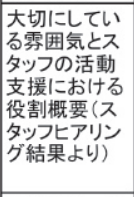 & $\begin{array}{l}\text { 学年の上下関係に } \\
\text { とらわれずんんな } \\
\text { で一緒に遊ぶ需囲 } \\
\text { 気を切にし、見 } \\
\text { 守りを中心に支援 } \\
\text { している。 } \\
\text { 拠点に1人は配置 } \\
\text { している。 }\end{array}$ & $\begin{array}{l}\text { 学年の上下のつ } \\
\text { ながりを大切によ } \\
\text { く遊ぶ需囲気を大 } \\
\text { 切にし、見守りを } \\
\text { 中心に支援してい } \\
\text { る。 } \\
\text { 拠点に1人は配 } \\
\text { 置している。 }\end{array}$ & $\begin{array}{l}\text { 家庭的な雲囲 } \\
\text { 気大切にし、 } \\
\text { 見守りを中心 } \\
\text { に支援してい } \\
\text { る。 } \\
\text { 拠点に1人は } \\
\text { 配惪している。 }\end{array}$ & 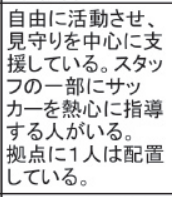 \\
\hline & 利用スペース & $\begin{array}{l}\text { 体育館、中庭、校 } \\
\text { 庭 }\end{array}$ & $\begin{array}{l}\text { 校庭、校外近郊 } \\
\text { (体育館、図書室 } \\
\text { も利用可能) }\end{array}$ & $\begin{array}{l}\text { 図書室、体育 } \\
\text { 館、中庭、前 } \\
\end{array}$ & $\begin{array}{l}\text { 多目的室、体育 } \\
\text { 館、校庭 }\end{array}$ \\
\hline \multicolumn{2}{|c|}{ 学童保育(児童クラブ) } & 有り & \begin{tabular}{|l|l} 
無し \\
\end{tabular} & 有り & \begin{tabular}{|l|l} 
無し \\
\end{tabular} \\
\hline \multicolumn{2}{|c|}{ 実態調査日 } & \begin{tabular}{|l|}
$\mathrm{H} 21.6 .11$ \\
$\mathrm{H} 21.10 .15$
\end{tabular} & \begin{tabular}{|l|} 
H21.6.4 \\
H21.9.17
\end{tabular} & \begin{tabular}{|l|}
$\mathrm{H} 22.7 .2$ \\
$\mathrm{H} 22.7 .9$
\end{tabular} & $\begin{array}{l}\text { H22.7.5 } \\
\text { H22.7.12 }\end{array}$ \\
\hline
\end{tabular}

\section{5. 時間別場所別の活動人数の考察}

以下では、図 1〜 4 の中に示寸時間別場所別および男女別の活動 児童数とスタッフ数の集計結果を用いて、児童の活動場所の選択傾 向、性差による活動場所の違い、スタッフの支援方法を分析する。 5-1. T I 小の活動人数の分析（図 1)

1 ) 児童数：1 日目の調查開始時は拠点の家庭科室での授業が延長 していたため、体育館の使用が 5 割近くを占めていた。途中 16 時 台に家庭科室が使えるようになると徐々に体育館から家庭科室へ移 っていった。2 日目の調查開始時には学校の取り組みで体育館を使
えなかったため、屋外を使用する人数が最も多かった。1 日目と比 べ、体育館の人数が減り、屋外の人数が増えていたことから、子ど も教室開始時の活動場所がその後の活動場所の選択に影響している 事が考えられる。

2）男子と女子の性差 : 男子は 1 日目に体育館の使用が最も多かっ た。調查開始時は、体育館の使用がほとんどだったが、1 6 時頃か ら人数が減り、屋外の人数が増えていた。2 日目は屋外の使用が大 半を占めた。1 日目と合わせて、男子は体育館や屋外などの運動で きる場所を多く使用していることがわかった。女子は 1 日目の調査 開始時は 4 つ場所に分散していたが、16:15 頃から家庭科室の人 数が多くなっていた。2 日目の開始時には、使えなかった体育館以 外の場所に分散し、15：30 に屋外の人数が最も多くなっていた。そ の後は 1 日目と同様に、1 6 時頃から家庭科室の人数が多くなって いる。男子に比心゙て女子は、室内での活動が多い傾向が分った。

3) スタッフ数：1 日目は合計して家庭科室内のスタッフ数が最も 多かった。この理由は、室内の折り紙などの活動を支援するために 多くのスタッフを配置したためである。体育館は児童数に比べてス タッフ数が少なく、体育館は見通しが良いため児童の動きを把握し やすく少ないスタッフでも対応できることがわかった。2 日目は屋 外のスタッフ数が児童数の傾向と同じく最も多く、広い屋外を多く の人数で見守っていることが分る。中央に位置する中庭にスタッフ のいない時間が多かったのは、スタッフの中で中庭は通路的な空間 という認識が強いためと考えられる。2 日間でスタッフは 1 人当た り約 8 人の児童を支援していた。

\section{5-2. NA 小の活動人数の分析（図 2)}

1) 巟童数：1 日目は、はじめ専用室が多く、徐々に屋外の人数が 増え、1 7 時以降は専用室のみになり、その後は人数が減り、時間 を決め専用室に集まり迎えを待っていることがわかる。2 日目は、 1 日目と比べ外で遊ぶ人数が多くなっていた。これは、子ども教室 の時間が短縮したことにより、1 日目の調查時には宿題などをして いた児童も遊びを優先するようになったためであると考えられる。 2 ）男子と女子の性差 : 男子は 1 日目、 2 日目共に屋外の活動人数 が多く、1 日目は $16 ： 00 \sim 16: 45 、 2$ 日目は $15 ： 45 \sim 16: 15$ まで 屋外だけを使っていた。女子の 1 日目は専用室での活動が多く、2 日目は屋外が多かったが、男子と比べて女子は、専用室を多く活用 寸る傾向があった。

3) スタッフ数：児童の傾向と同じく、1 日目は 16 時頃から徐々 に屋外のスタッフ数が増え、16:45 に最多になっている。スタッフ は児童の動きに合わせて動いていることが読み取れる。2 日目は屋 外に児童がいる時間は 2 名の内の 1 名が屋外の見守りを行っている。 両日共に専用室に必ず 1 人はスタッフがおり、拠点内を見守る仕組 みだった。 2 日間でスタッフは 1 人当たり約 3 人を支援していた。

\section{5-3. FU小の活動人数の分析（図 3 )}

1) 巟童数：1日目と 2 日目共に拠点の多目的室付近の活動が多か った。これは多目的室の床面積が約 $256 \mathrm{~m}^{2}$ と広く、多人数が活動で きる広さの余裕があるためである。1 日目 2 日目共に開始直後に多 目的室に集まり、その後他の場所で活動し、時間が経つにつれて徐々 に多目的室に戻ってきていることが読み取れる。数名ずつではある が多目的室の隣の図書室の利用も見られた。多目的室が 2 階にある ため、開始後 15 分から 30 分後に中庭や前庭へ活動が広がってい 

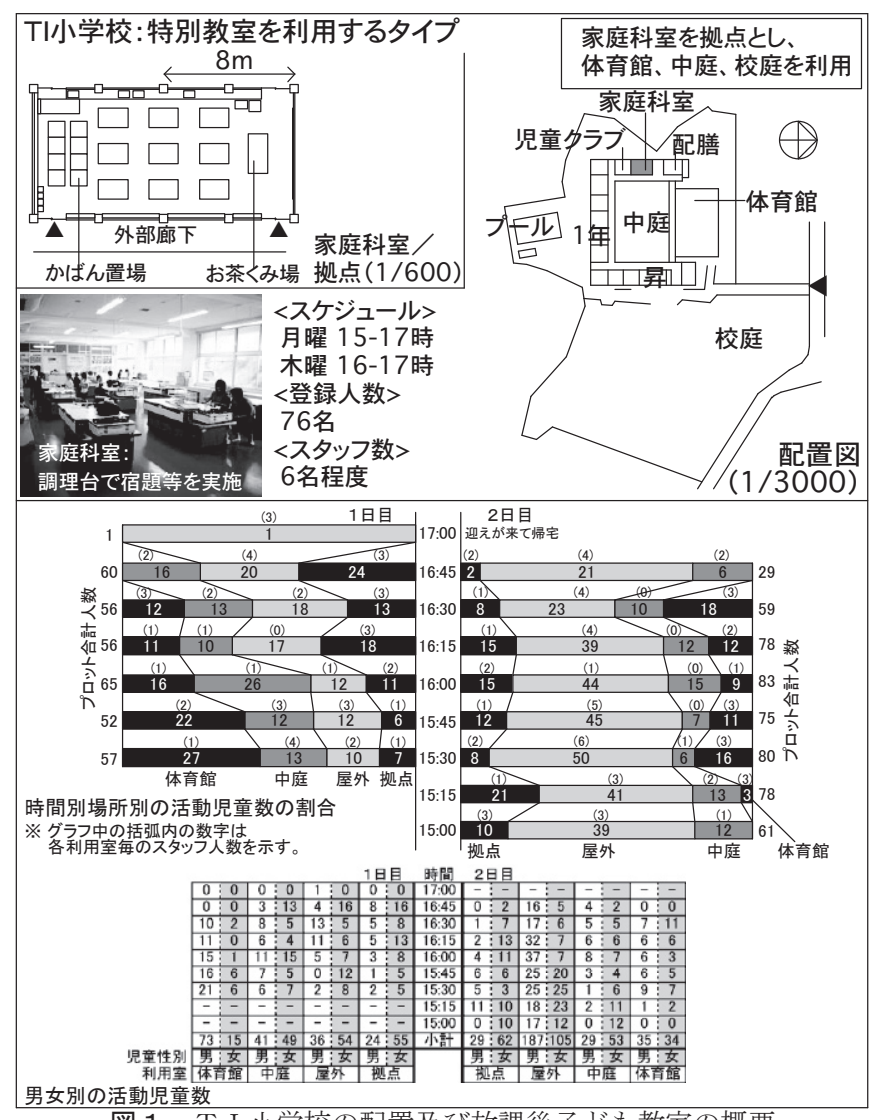

図 1 T I 小学校の配置及び放課後子ども教室の概要

FU小学校:多目的教室を利用するタイプ

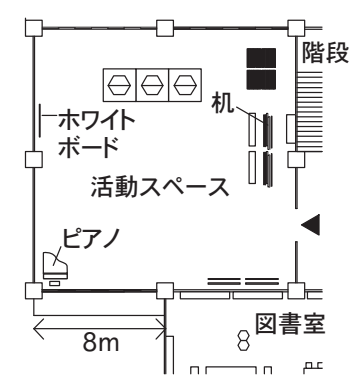

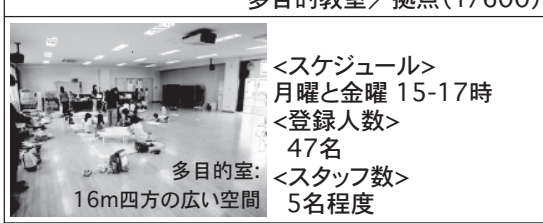


時間別場所別の活動児童数の割合

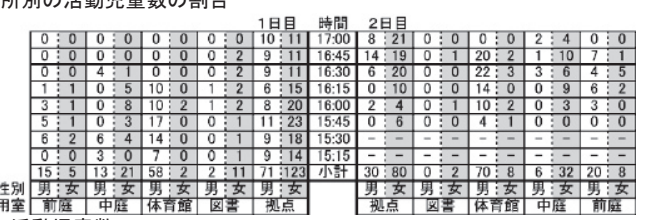

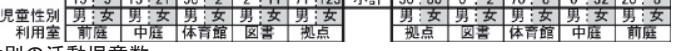
男女別の活動児童数

図 3 F U小学校の配置及び放課後子ども教室の概要
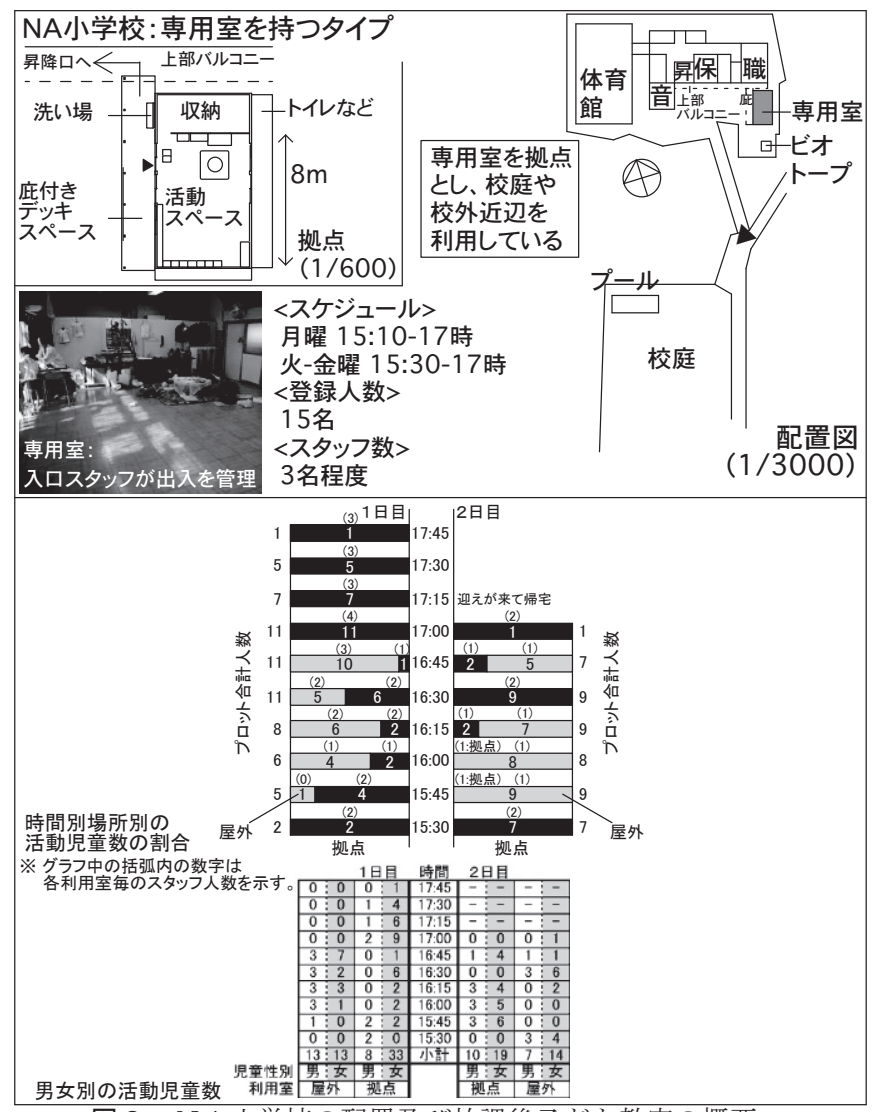

図 2 N A 小学校の配置及び放課後子ども教室の概要

SI小学校: 複数の多目的スペースを利用するタイプ
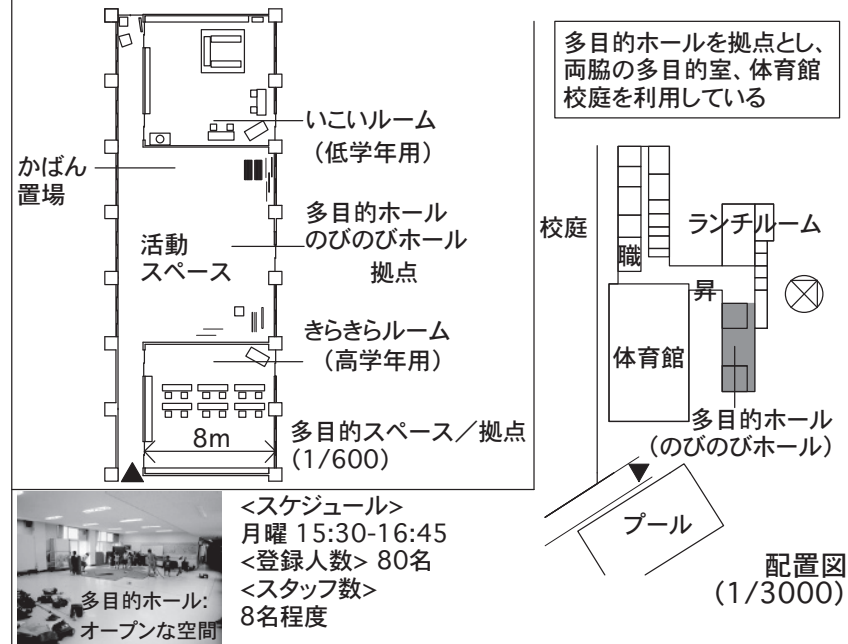

$(1 / 3000)$

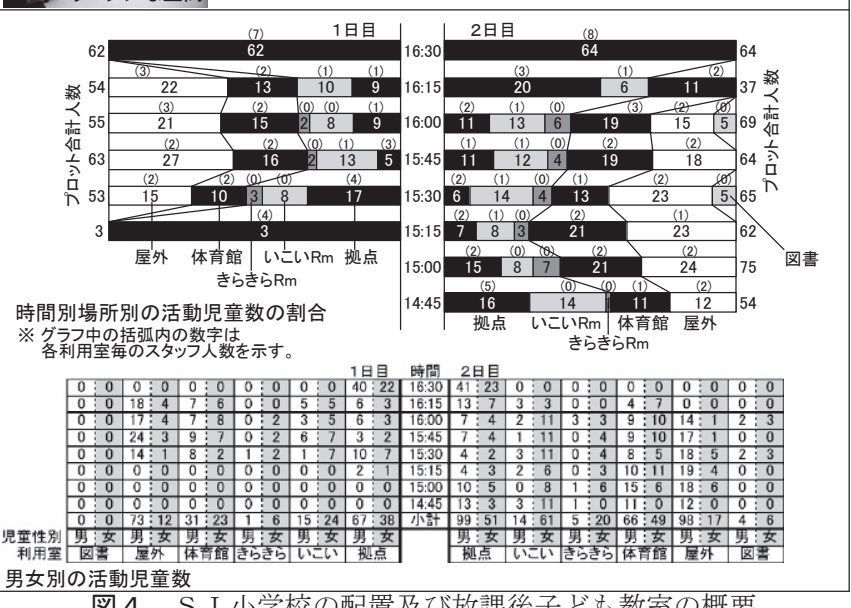


く様子が把握できた。

2 ）男子と女子の性差 : 男子の 1 日目の合計人数は多目的室付近が 最も多いが、16:30 に地域活動のために体育館が使えなくなるまで は、体育館の活動人数が最も多くなっている。また 2 日目にはほと んどの男子が体育館で活動している。女子は 1 日目と 2 日目共に多 目的室付近の活動が最も多く、次に中庭が多かった。体育館は 2 日 目の $16: 30$ の 3 人が最多であった。体育館の活動人数が男子と女子 で最も違いが見られた。

3) スタッフ数： 1 日目と 2 日目共に拠点の多目的室に最も多くの スタッフがいた。1 日目の 15:30〜16:30 まで前庭にスタッフがいな いのは、中庭と前庭が行き来しやすくスタッフが見回りながら支援 していたためである。2 日目は前庭の遊具利用の児童が多いため、 スタッフもいた。スタッフ 1 人当たり約 9 人を支援していた。

\section{5-4. S I 小の活動人数の分析（図 4)}

1 ) 児童数: SI 小では子ども教室終了時に拠点に集合して挨拶を行 い多くがスクールバスに乗るため、16:30の人数は 2 日とも拠点 のみである。1 日目は屋外の活動人数が最も多く、2 日目は屋外と 体育館が同程度の人数で多く利用されている。一方で、1 日目 2 日 目共に拠点・きらきらルーム・いこいルームの活動人数を合わせる と全体の 4 割程度を占め、拠点廻りも良く利用されている。

2) 男子と女子の性差 : 男子は 1 日目と 2 日目共に屋外の活動人数 が最も多い。屋外と体育館を合わせると、男子全体の人数の 8 割程 度を占めていることが分かる。女子は 1 日目と 2 日目共に、主に低 学年が宿題を行ったり玩具なども置いてある「いこいルーム」の活 動人数が最も多く、高学年が宿題を行う「きらきらルーム」や図書 室も多い。男子と比べ女子は拠点付近を利用していた。

3 ) スタッフ数：1 日目と 2 日目共に、合計人数では拠点のスタッ フ数が最も多かった。2 日を通して、高学年が宿題を行う「きらき らルーム」ではスタッフ数が 0 人で、高学年のためスタッフを配置 していない。また、「いこいルーム」も最大 1 人で、小部屋であるた め見守りやすく多くのスタッフを必要としない。学年ごとに分けて 利用できる部屋が複数あるとスタッフ人数の配分を考えやすいメリ ットがある。 2 日間でスタッフは 1 人当たり約 8 人を支援していた。 また、「いこいルーム」「きらきらルーム」の児童数を除いた場合は、 1 人当たり 6.6 名とより細かく児童を支援できていた。

\section{5-5.4 校の比較考察}

・览童は、子ども教室の終了時間が近づくにつれて、拠点での活動 人数が増えていく傾向が見られた。児童は終了前の集合時間を意識 して活動している事がわかった。

• 児童の活動場所の選択には、開始時間時に使用可能な場所の種類、 活動時間の長さ、拠点の広さや学年の高低が関係している。

- 児童の性差も活動場所の選択に影響を与えており、全般的に男子 は体育館や屋外などの運動できる場所を好んで利用し、女子は男子 と比べると屋内空間を好んで利用寸る傾向がある。

・スタッフは児童の移動と活動場所の見守りや寸さに合わせて、支 援人数が増減する傾向が見られた。

・スタッフの配置人数は、 $\mathrm{T} \mathrm{I}$ 小は児童約 8 人に対し 1 人、 N A 小 は約 3 人に対し 1 人、F U 小は約 9 人に対し 1 人、S I 小は約 8 人 に対し 1 人配置しており、いずれの事例も松江市の支援基準である 児童 10 人に対し 1 人よりも手厚く配置されていることが分った。

\section{6. 場所別にみた活動内容の考察}

以下では図 $5 \sim 8$ に示寸事例別の場所別・活動別にみた活動内容 の分析図(調查 2 日間の合計)を用いて活動内容の詳細を分析する。 また、場所の特性と活動内容との関係を捉えるため、調査で見られ た多様な活動形態を表 4 に示すように静的活動と動的活動の 2 種類 に分類した。この 2 種類の分類は既往研究注 6) の分類方法を参考に、 宿題や読書などを静的活動、鬼ごっこやボール遊びなどのレクリエ ーションやスポーツ活動を動的活動として分類を行った。

\begin{tabular}{|c|c|c|}
\hline & 静的活動 & 動的活動 \\
\hline 注6)での分類 & 宿題支援や学習 & レクリエーションやスポーツ \\
\hline \multirow{10}{*}{$\begin{array}{l}\text { 4校の } \\
\text { 放課後 } \\
\text { 子ども } \\
\text { 教室で } \\
\text { 見られた } \\
\text { 活動内容 }\end{array}$} & 会話 & \multirow{3}{*}{$\begin{array}{l}\text { ボール遊び } \\
\text { •バスケット・サッカー } \\
\text { •ドッジボール } \\
\end{array}$} \\
\hline & 宿題 & \\
\hline & 歌 & \\
\hline & \multirow{7}{*}{ 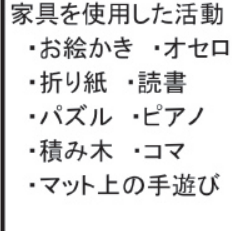 } & 遊具を使用した遊び \\
\hline & & ·一輪車 ·フラフープ \\
\hline & & •なわとび \\
\hline & & 設置遊具による遊び \\
\hline & & •ブランコ・鉄棒 \\
\hline & & 虫取り、魚取り \\
\hline & & 鬼ごっこ \\
\hline
\end{tabular}

\section{6-1. T I 小の場所別の活動内容分析（図 5 ）}

静的活動と動的活動は 4：6の人数比で行われていた。(1)拠点の 家庭科室では、静的活動が主でお絵かき・折り紙・オセロ、机やホ ワイトボードの家具を使った活動が最も多く、次に宿題をする人数 が多かった。(2)拠点前の廊下では、スタッフや児童の通行やその際 の会話が多く見られた。特に調查 1 日目は開始時に家庭科室が使え なかったため、廊下に長机を設置し、宿題をする様子が見られた。 特別教室を拠点する際には、その室が利用できないときに備えて補 助的な室を事前に計画する必要がある。(3)中庭では、多様な活動が 行われ、特に友人同士で話寸児童が最も多かった。土管やタイヤの 山などが、数人単位の児童の居場所を作り出すことで、会話の生ま れ易い環境を作り出している。(4)体育館では、バスケットなどのボ 一ル遊びが多かった。体育館の外側にボールなどの遊具を入れるこ とのできる専用のベンチをこども教室開設時に設けており、この工 夫が生かされている。(5)屋外では、サッカーをしている人数が多か った。これは全ての場所の中で最も参加人数の多い活動であった。

\section{6-2. NA小の場所別の活動内容分析（図 6)}

静的活動と動的活動は 5：5の人数比で行われていた。(1)専用室 では、お絵かき、読書、パズル、宿題などを行う人数が多かった。 さらに、専用室内で鬼ごっこをする様子もあり、専用室では静的活 動だけでなく、学校側に気兼ねなく動的活動もしやすい自由な雾囲 気がある事がわかった。また、専用室前にデッキ部分が整備されて いるため、靴を脱がずに内部の人と会話がしやすく、専用室入り口 付近で話をする児童が多かった。(2)屋外（専用室近く）には、ビオ トープがあるが、プロット調査時はあまり使われていなかった。し かし、事前に訪問した際にはビオトープで多くの児童が虫取りをし ていた事から、時期や生物の状態によっては遊び場になっている。 (3)校庭及びその他屋外では、ブランコや滑り台などの遊具を用いて 遊ぶ人数が多かった。その他に学校の敷地外に出て水路や川で虫取 りなどをして遊ぶ人数が多かった。周囲に豊かな自然環境があるメ リットが生かされている。 
6-3. F U小の場所別の活動内容分析（図 7 )

静的活動と動的活動は 5：5の人数比で行われていた。(1)多目的 室は約 4 教室分の広さを持つため、家具を使用して大きく広がる活 動が多く、長机を自由に動かしておりがみやお店ごっこを多く行っ ていた。静的活動だけでなく、なわとびやボール遊びなどの動的活 動も行っていた。(2)図書室は多目的室と隣接し、読書を行う览童が
見られた。(3)体育館では、ドッジボールなどのボール遊びが最も多 かった。これは全ての場所の中で最も参加人数の多い活動であった。 (4)中庭では、一輪車などの遊びが多く、スロープの手すりや、体育 館前の柱が役立っていた。(5)前庭では、設置遊具で遊ぶ児童が多く みられた。中庭とつながっているため一体的に利用でき、一輪車で 行き来しながら遊ぶ児童も多い。

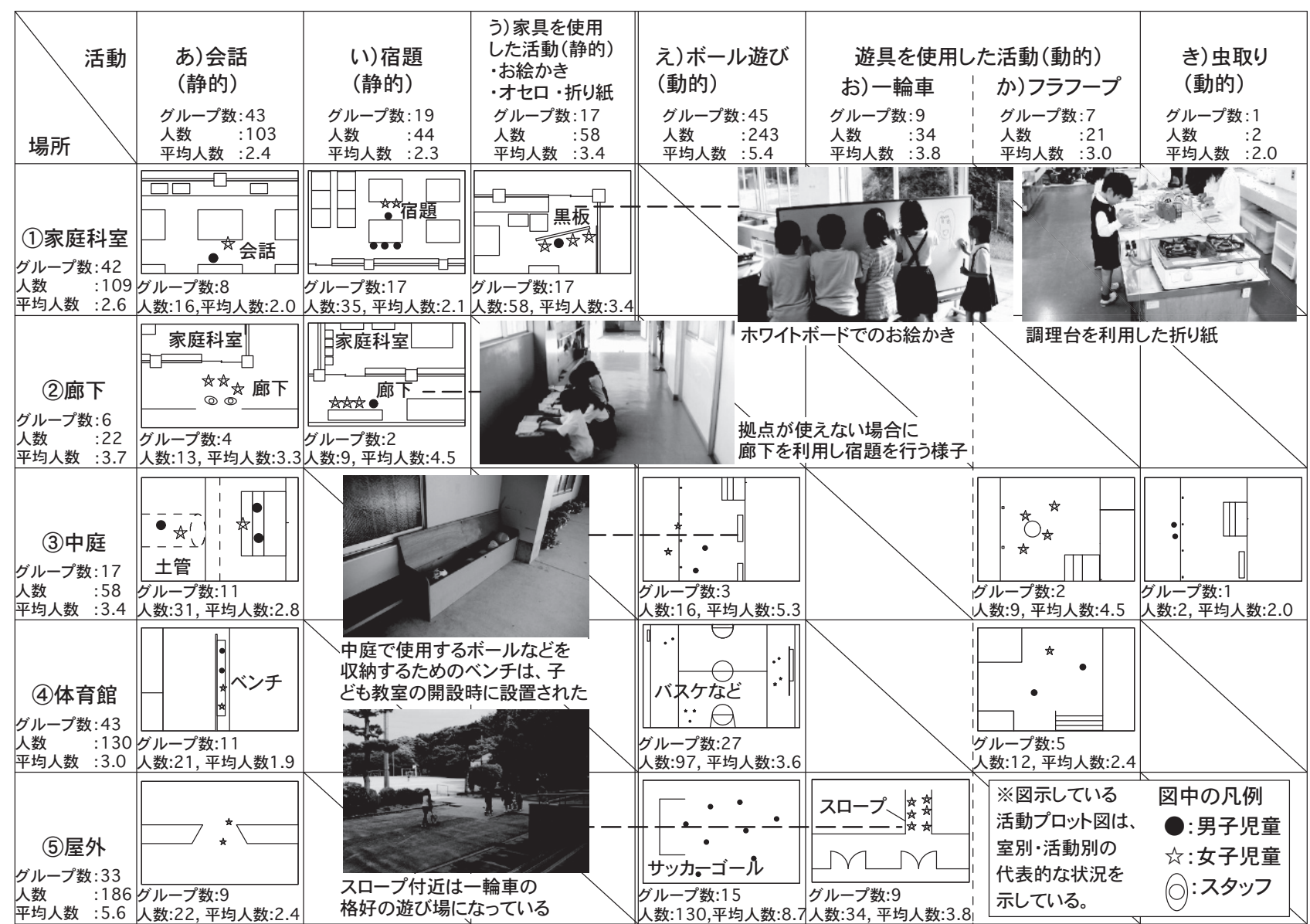

平均人数 : 5.6 人数: 22 , 平均人数: 2.4

人数: 130 平均人数: 8.7 人数: 34 , 平均人数: 3.8

示している。

(○):スタッフ

図 5 T I 小学校の場所別・活動別にみた活動内容の分析図（2 日分の集計）図中の「平均人数」は「人数/グループ数」を示す。

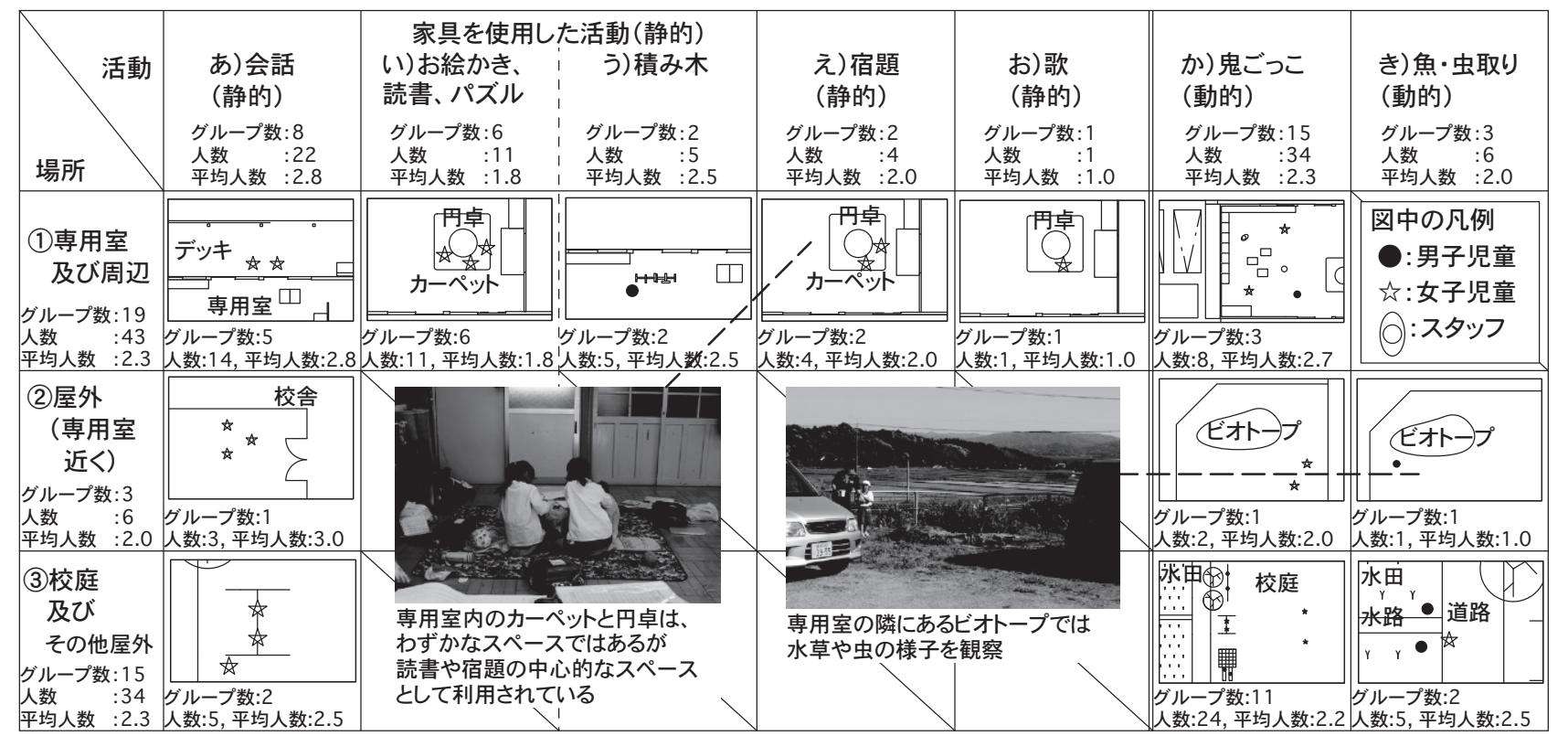

図 6 NA小学校の場所別・活動別にみた活動内容の分析図（2 日分の集計）図中の「平均人数」は「人数/グループ数」を示す。 


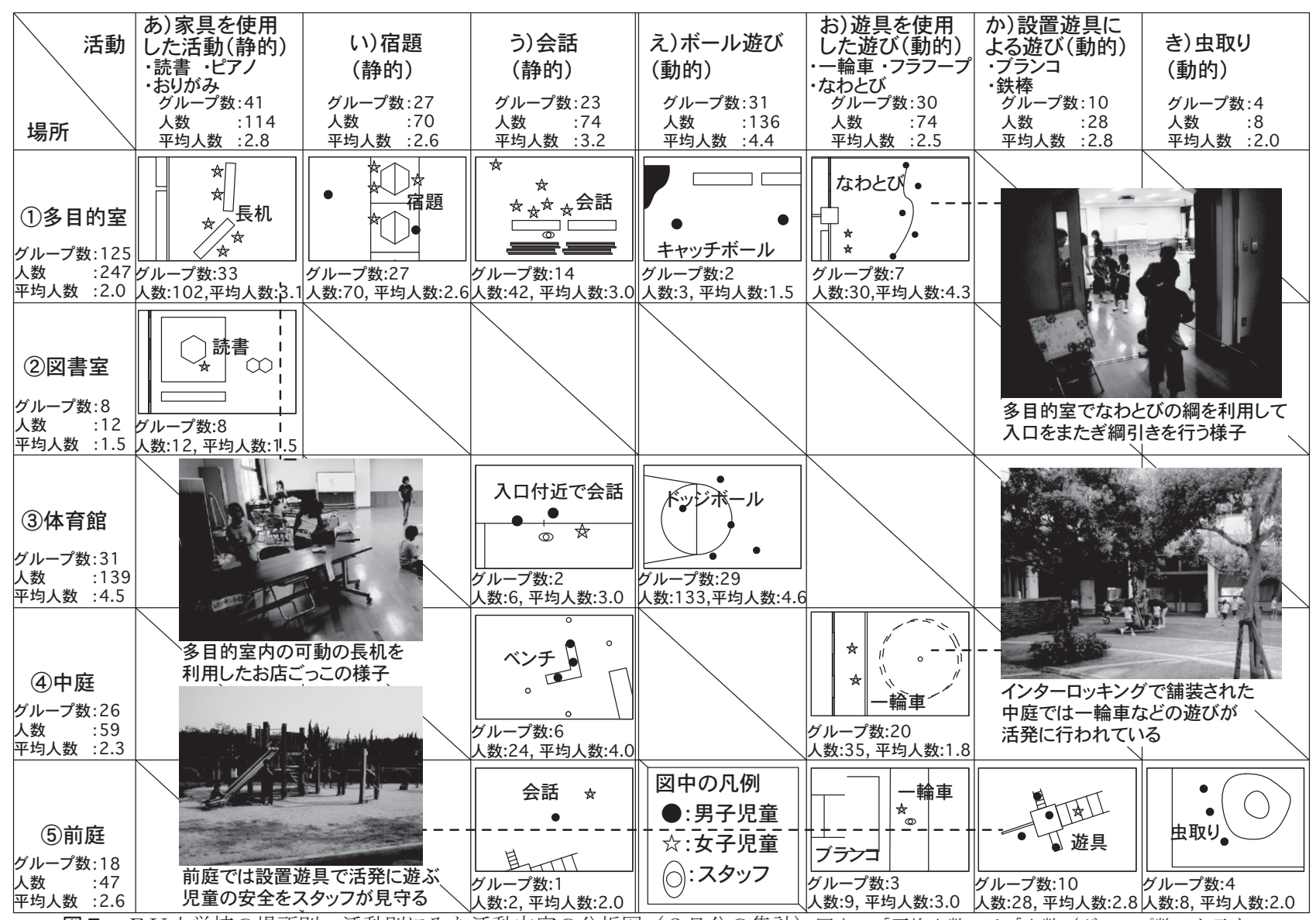

図 7 F U小学校の場所別・活動別にみた活動内容の分析図（2 日分の集計）図中の「平均人数」は「人数/グループ数」を示す。

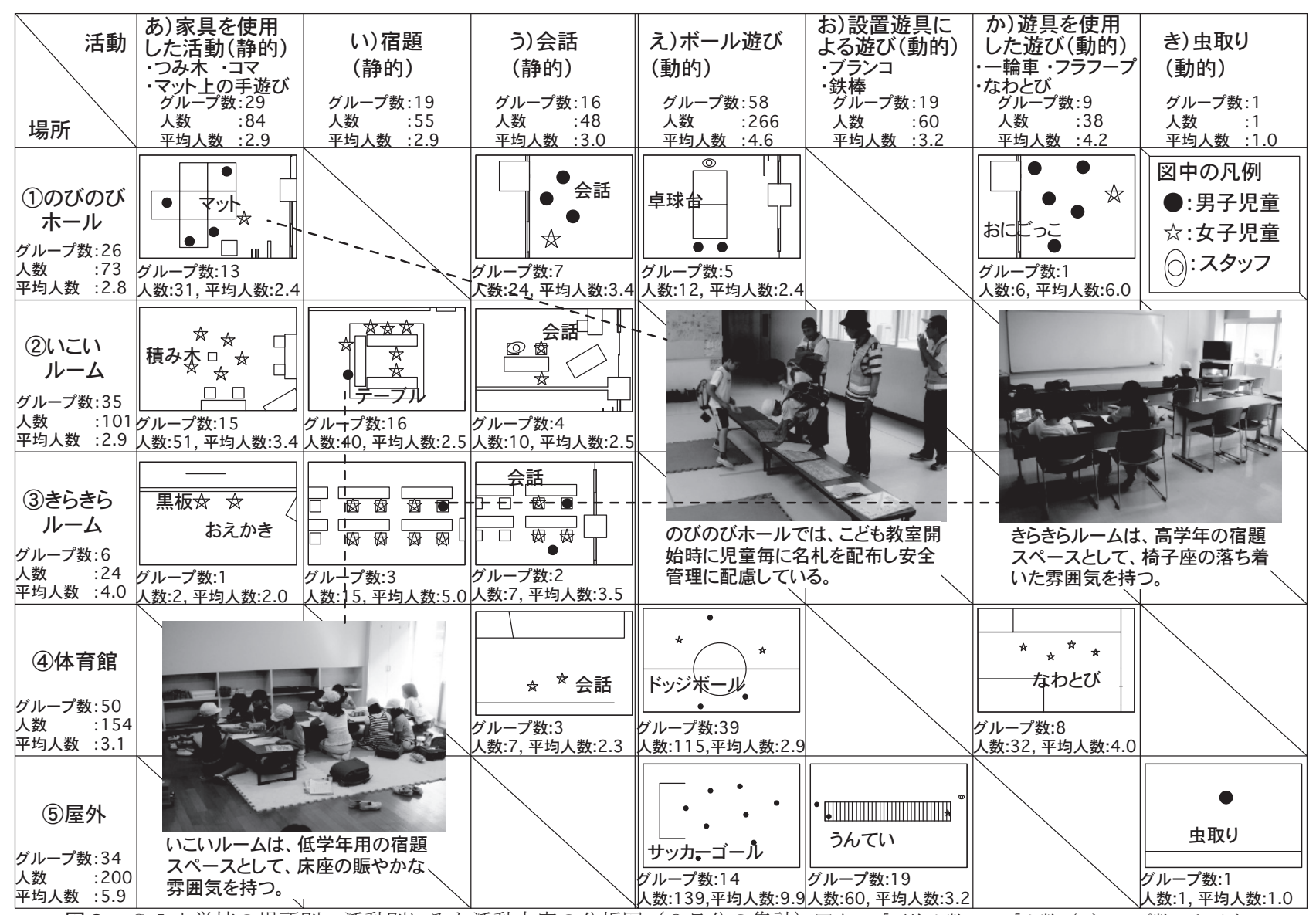

図 8 S I 小学校の場所別・活動別にみた活動内容の分析図（2日分の集計）図中の「平均人数」は「人数/グループ数」を示す。 


\section{6-4.S I 小の場所別の活動内容分析（図 8)}

静的活動と動的活動は $3: 7$ の人数比だった。他の学校に比べて 動的活動の割合が高いのは、体育館や屋外でのボール遊びが非常に 活発に行われていたからである。(1)拠点となる「のびのびホール」 では、マットを用いた遊びの人数が最も多かった。会話の人数も最 も多く、児童同士やスタッフとの交流の場となっていることがわか る。静的活動だけでなく、卓球などの動的活動も盛んであった。(2) いこいルームは、床仕上げがカーペットで床座になれるため、低学 年の宿題と共に、積み木やコマなどで遊ぶ人数が最も多く見られた。 (3)きらきらルームは、長机と椅子のスクール形式の家具配置である ため、主に高学年が宿題を静かな空間で取り組めていた。このよう に拠点と両隣の 3 室は活動種類や高低の学年別に使い分けられてい る。(4)体育館では、ドッジボールなどのボール遊びが多く、グルー プ数で最多の活動であった。(5)屋外では、サッカーが最も多く、児 童数で最多の活動であつた。

\section{6-5.4 校の比較考察}

・ N A 小、F U小、 S I 小の拠点では、静的活動と動的活動の両方 が行われていた。しかし、特別教室を拠点とする T I 小は固定家具 のため動的は行われていなかった。学校の一室を拠点にする場合は、 固定家具のない多目的室の方が児童は自由な活動を行えていた。 - 静的と動的の人数比は 2 日間の合計で、静的が最少のS I 小で 3 : 7 、 $\mathrm{T} \mathrm{I}$ 小が 4 ：6、静的が最多の N A 小と F U小で 5 ： 5 であっ た。 S I 小で動的に偏ったのは、校庭のサッカーと拠点での動的が 多かったためである。4 例はいずれも宿題支援だけでなく、N A 小 での田んぼの虫取りやS I 小の卓球やサッカーなど、スタッフの協 力を得た自由な活動を行えていることが分った。

• 図 5 から図 8 の図中に示すグループ平均人数から、静的活動の宿 題は 2.0 人から 5.0 人で、宿題を 1 人で行うことは少なく、拠点室 もしくはその周辺の室を利用しながら複数人のグループ単位で行う ことが分った。拠点室は宿題支援を想定して、複数人で学習できる コーナーや家具を用意する必要がある。

・学校毎のグループ数と人数が多い場所・活動では、T I 小と S I 小が体育館や校庭でのボール遊び、N A 小が拠点室での会話や校庭 での鬼ごっこ、F U小が体育館でのボール遊びと多目的室での家具 を使用した活動であった。これらの内で、ボール遊びはグループ平 均人数も 5 人以上の場合が多く、子ども教室が学校の体育館や校庭 を活用することで、多人数が交流し活動する機会を作り出しており、 学校施設を活用した子ども教室のメリットの 1 つと言える。

・会話は拠点室以外でも中庭で良く見られた。中庭を持つのはT I 小と F U 小で、 T I 小では中庭の築山と体育館の外側で中庭に面し た部分のベンチ、F U小ではベンチで会話するグループが多く、次 の活動場所への移動時の小休您などに有効に活用されている。

\section{7. 拠点室の配置および設置方法別のメリット・デメリットについ ての考察 (図 9 )}

以下では、これまでの分析結果から明らかにした内容を集約し、 子ども教室の児童の管理や静的活動などの拠点として重要な場所で ある拠点室の配置および設置方法の違いによって児童の活動にどの ような影響が及んでいるかを考察する。

1） T I 小にみられる特別教室を拠点とする場合（図 9 (1)）家庭
科室を拠点とする T I 小は、拠点が中庭・体育館等と近いためこれ らの場所をスムーズに活用できていた（4、5-1より）。しかし、 拠点での授業が長引くと点呼場所や私物の保管場所を失うことがあ る ( 6-1より)。補助的な代替拠点の想定が必要と思われる。また、 特別教室であるため、すでに多くの実習教材が収納してあり、子ど も教室の教材や活動遊具などの収納スペースの確保が難しいデメリ ットもあった ( 4 より)。

2) N A 小にみられる別棟の専用室を拠点とする場合 (図 9 (2) ) 専 用室を持つN A 小は、授業の影響を受けず活動でき（6-2より）、 収納スペースも十分確保できていた（4より）。さらに、屋外へのア クセスの容易さもメリットである $(5-2$ より)。参加児童数が最大 11 名と小規模で、専用室で静的と動的の両方の活動が可能であつ たためもあるが、利用可能な校舎内の図書室や体育館での活動は、 ヒアリング調査時および実態調査時共に無かった。

3） F U小にみられる 2 F多目的教室を拠点とする場合（図 9 (3) 校舎 2 階の多目的室を拠点とする F U小は、約 4 教室分 (16 m四 方、約 $\left.256 \mathrm{~m}^{2}\right)$ の広さから、静的と動的の両方が行えている（63 より)。また多目的室は図書館と隣接していることから、子ども教 室時にも図書が利用しやすいメリットがある（5-3より）。デメリ ットは、拠点が 2 階で外に出るのに時間がかかり、中庭などがべラ ンダ越しに見えても屋内と屋外のつながりが良くない点が挙げられ る。また、中庭型校舎で子ども教室を運営するメリットとして、中 庭・前庭・体育館の行き来がし易く、特に中庭はスタッフの目が行 き届き易い $(5-3$ より)。中庭は活動場所への移動時の小休憩スペ 一スとなり、児童間の会話を生み出し易い（ $6-5$ より）。

4） S I 小にみられる複数の多目的スペースを拠点とする場合（図 9 (4)） オープンな多目的ホールを拠点とし、両脇の 2 室も利用で きるS I 小は、学年別や活動別に使用室を区分し、高学年の宿題、 低学年の宿題、動的活動に使い分けできる大きなメリットを持つこ とが把握できた（6-4より）。これはスタッフ配置にも影響してお

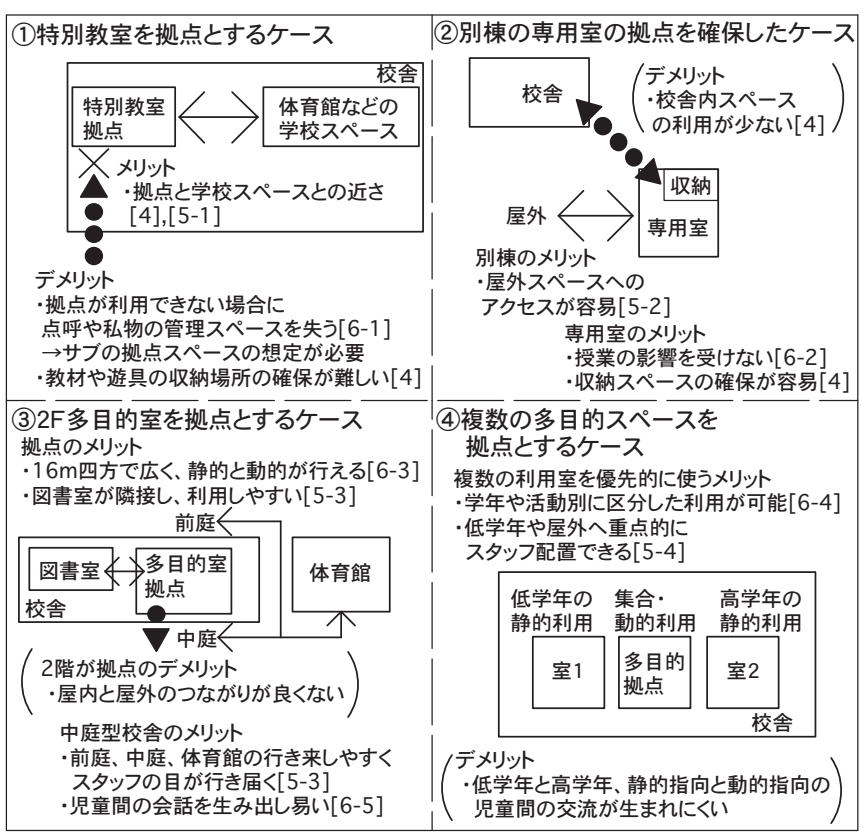

図 9 拠点室の配置および設置方法別の分析図 ※図中の [ ]内の数字は、本文中の考察箇所の章を示す。 
り、高学年の宿題に使用する室では、自分たちのペースで学習させ て見守りのスタッフは配置せず、屋外での動的活動などにスタッフ を多く配置するなど、効率的なスタッフ配置も可能にしていた（54 より)。一方で、デメリットとまでは言えないが、学年別や活動別 に使用する室を区分しすぎる場合があるとすれば、異学年間や活動 グループ間での多様な交流を妨げてしまうことも考えられる。

\section{8. 結論}

・拠点の設置方法が異なる 4 校の活動場所やスタッフの支援の実態 を明らかにできた。(1)览童の活動場所の選択には、開始時に使用可 能な場所の種類、活動時間の長さ、拠点の広さや学年の高低が関係 している。また、児童の活動種類や活動場所の選択には、性差も大 きく影響し、男子は屋外や動的を好み、女子は拠点での宿題や家具・ 道具を利用する活動が多い。(2)スタッフの支援では、いずれもスタ ッフ 1 人当り児童 $3 \sim 9$ 名程度の少人数で支援しており、静的活動 と動的活動の人数比は $3 ： 7$ から 5 ：5で、スタッフによって安全 が確保された遊びと学習の両面の時間と場所を提供していることが 分った。空間の広さによる見通しの良さを利用したり、支援の手間 が少ない高学年の活動拠点を明確にすることで、低中学年へのスタ ッフの見守り易さは向上する。

・子ども教室における活動場所と活動内容との関係を考察した。(1) 宿題は、拠点室もしくはその周辺の室を利用した $2 \sim 5$ 人の複数人 のグループ単位で行うことが分った。拠点室の整備時には、宿題支 援を想定した複数人で学習できるコーナーや家具を用意する必要が ある。(2)体育館や校庭でのボール遊びはグループ平均人数が 5 人以 上の場合が多く、多人数が交流し活動する機会を作り出している。 これは学校施設を活用して子ども教室を開設する場合の大きなメリ ットであると言える。(3)中庭型校舎の T I 小と F U小では、児童間 の会話が拠点室だけでなく中庭でも多く見られた。築山やベンチで 会話するグループが多く、次の活動場所への移動時の小休数にも活 用されている。放課後の子ども教室において中庭空間が果たす役割 を明らかにできた。

・拠点の設置方法別のメリットとデメリットを考察し、この結果か ら、以下に今後の拠点整備の際に留意すべき要点を挙げる。事例毎 に長所短所はあるが今後の校舎の整備や改修の際には子ども教室の 開設を見越し、(1)児童が静的と動的の両方の活動ができる場を用意 する必要がある。静的と動的の両方に対応した床仕上げ、かばん等 の私物や教材の収納等、実際の運用を想定した計画が求められる。 (2)拠点室は点呼・保護者の引き取りの際の集合場所であると共に宿 題支援・会話・家具を使用した活動も行える空間として、屋外から アクセスし易く、十分な広さを持つ室として整備することが求めら れる。図書室や屋外スペースとつながりの良い場所に配置すれば多 様な活動に対応できる。また、登録児童数にもよるが、(3)子ども教 室が、学校の授業・行事や地域開放などに対し優先的に拠点として 利用できる室・スペースを確保できれば、授業などの延長で拠点を 利用できなくなる等の問題を防ぐことができる。さらに、そのよう な拠点室を複数確保できれば、学年の高低別や活動内容別の使い分 けも可能になる。特に、特別教室や体育館を拠点室として利用寸る 場合は地域利用の影響を受け易いため、多目的室の拠点室への利用 や拠点専用室の整備が望まれる。

\section{謝辞}

本調查分析は、日本学術振興会科学研究費補助金若手研究 (B) 「実態調查に基づいた地域が協力し易く安全も確保した放課後子ど も教室の空間モデル構築 (平成 21-23 年度、若手研究 B : 21760468)」 の一環として実施した。

この調查および集計に関しては、安川大地氏（米子高専専攻科建 築学専攻修了生）から多大な協力を得た。また松江市教育委員会、 公民館職員、調查校の教職員や子ども教室支援スタッフの方々にも 心良く調查にご協力いただいたことを記し、謝意を表したい。

\section{参考文献}

1 ) 全国学童保育連絡協議会: よくわかる放課後子どもプラン, ぎょうせい, 2007. 4

2）斎尾直子, 長谷夏哉 : 都市における児童の居場所づくりの多様化と安全 安心一豊かな空間確保両立についての考察 -こども達の放課後の居場所づ くりに関する研究，日本建築学会計画系論文集，No. 614, pp. 33〜39, 2007. 4 3 ）松本歩子, 中山徹:「放課後子どもプラン」実施における学童保育のあり 方に関寸る研究 一一体化事業における保育機能の現状から-, 日本建築学会 計画系論文集，No. $635 ，$ pp. 33 40，2009. 1

4) 松本歩子, 中山徹 : 学童保育と全児童対策事業の連携のあり方に関する 研究 一「放課後子どもプラン」における学童保育の現状 その 2 -, 日本建 築学会計画系論文集，No. $655 ， p p .2115 ２ 124 ， 2010.9$

注

注 1 ）島根県教育委員会 : 放課後子ども教室および放課後児童クラブ 市町村 別実施状況, 2010.3

( http://www. pref. shimane. lg. jp/life/kyoiku/syougai/plan/index. data/ 21 kyousitu. kurabu. pdf)

この中で平成 19 年の島根県内全小学校区数に占める開設小学校区数の割合 は $41.6 \%$ である。この他に平成 19 年から 22 年の市町村別のデータを掲載 している。

注 2 ）文部科学省・厚生労働省放課後子どもプラン連携推進室 : 放課後子ど もプラン実施状況調查について, 2007.12

(http://www. mext. go. jp/b_menu/houdou/20/06/08061901. htm) (http://www. mext. go. jp/b_menu/houdou/20/06/08061901/001.pdf) この資料中の 7 頁に放課後子ども教室が未実施なのは、21,874 小学校区中 で 16, 167 小学校区 $(73.9 \%)$ であることが示されている。

注 3 ）島根県教育委員会・島根県健康福祉部編：平成 21 年度しま敞の放課後 子どもプラン連携事例集，2010.4

( http://www. pref. shimane. lg. jp/life/kyoiku/syougai/plan/index. data/ 21 jirei.pdf)

この中で連携先の種類別に、各市町の取組みが $5 つ$ つ分類されている。

注 4）総務省統計局：統計でみる市区町村の寸がた 2011

(http://www. stat. go. jp/data/ssds/5b.htm)

この中の「人口・世帯」データ内で松江市は人口 19 万 6 千人で全 785 市の 116 位である。この人口と「自然環境」データ内の総面積とで計算した人口 密度では、松江市は 370 (人/平方キロ）で 422 位である。

注 5 ) 平成 21 年度に調查した TI 小と NA 小では、事前のスタッフのヒアリン グ調查において、学期始めは児童が不安定であるため、1 1 月程度経た後に 調査を行った方が児童の自然な活動が把握できるとのアドバイスをもらい 1 学期と 2 学期のようすの違いも考慮して調查を実施した。一方で TI 小と $\mathrm{NA}$ 小共に 1 度目と 2 度目の調查間で使用する活動場所に違いは無く、活動 人数に違いを及ぼした原因は室が学校授業によって使用できなかったこと と開始や終了時刻の変化によるものであると判断できたため、FU 小と SI 小 では 1 学期の間に 2 度の調查を実施した。

注 6 ）渡邊昭彦，細田智久：アフタースクールの利用諸室における児童への 学習支援の実態分析一学校問題に対応寸るフルサービススクール等の米・英 実態調查研究 その $2-$, 日本建築学会計画系論文集, No. 617, pp. 31 38, 2007.7 の中で、宿題支援や英語、芸術や音楽学習等を静的活動、レクリエ ーションやスポーツ等を動的活動と定義している。

（2011年 6 月 3 日原稿受理，2011年12月16日採用決定） 